\title{
IdeAs
}

Idées d'Amériques

\section{E.P. Meinecke and the Development of the Modern Auto Campground}

E. P. Meinecke et le développement des aires de camping automobile, dans l'élan de la modernité.

E. P. Meinecke y el desarrollo de las áreas de campamento automóvil. Novedad y cultura de la modernidad

\section{Terence Young}

\section{(2) OpenEdition}

\section{Journals}

Electronic version

URL: https://journals.openedition.org/ideas/3502

DOI: $10.4000 /$ ideas.3502

ISSN: 1950-5701

\section{Publisher}

Institut des Amériques

\section{Electronic reference}

Terence Young, "E.P. Meinecke and the Development of the Modern Auto Campground", IdeAs [Online], 12 | 2018, Online since 19 March 2019, connection on 19 October 2022. URL: http:// journals.openedition.org/ideas/3502 ; DOI: https://doi.org/10.4000/ideas.3502

This text was automatically generated on 19 October 2022 .

\section{c) (i)}

Creative Commons - Attribution-NonCommercial-NoDerivatives 4.0 International - CC BY-NC-ND 4.0 https://creativecommons.org/licenses/by-nc-nd/4.0/ 


\title{
E.P. Meinecke and the Development of the Modern Auto Campground
}

\author{
E. P. Meinecke et le développement des aires de camping automobile, dans l'élan \\ de la modernité. \\ E. P. Meinecke y el desarrollo de las áreas de campamento automóvil. Novedad y \\ cultura de la modernidad
}

Terence Young

On the afternoon of July 8, 1932, Emilio Pepe Meinecke sat at his typewriter in a Honolulu hotel room banging out a report to Haven Metcalf, his supervisor in Washington, D.C. A plant pathologist in the US Department of Agriculture, Meinecke had come from San Francisco in early June to consult on vegetation in the territory's national park, but now he was finished and awaiting his boat to California. For the first three pages, he detailed the successful work he had just completed in the islands, but then on page four Meinecke changed the subject. "Have you any funds for travel," he asked, "and if so, how much can I spend?" The issue was on Meinecke's mind because he had lately become something of a celebrity and was being badgered to appear at national parks across the country. "The demands for advice and visits are coming fast and furious," he moaned. "The Yosemite is howling, the Sequoia Park bombards me with letters and the Mesa Verde is putting all its new 6-year camp ground plans off until I come to help them. And that is only part of the story. I almost wish I had never written that Camp Ground Policy. Requests for copies and help are coming from all sides. I must have sent out two or three hundred mimeographed copies, and still they want more" (Meinecke, E., 1932d: 4)

Despite Meinecke's exasperation and momentary regret, he and his Camp Ground Policy sit at the center of this historical account. An under-recognized pioneer at the frontier between American culture and nature, Meinecke was unwittingly drawn into an emerging environmental discussion between 1925 and 1935 about natural landscape design, policy and practice in America's most popular protected areas. His emergence as a central figure in the ongoing tension between America's modern and anti-modern 
tendencies is unexpected because Meinecke had no formal training in landscape architecture or a related practice. Nevertheless, he imagined and designed what became one of the nation's most popular settings for engaging nature - the automobile campground. ${ }^{1}$

In this article I use historical methods and archival sources to illustrate how Meinecke's plans attempted to balance campers' desire to escape modern urban life with his own and campground managers' concern to protect natural settings from the environmental damage that resulted from heavy camper use. Ironically, Meinecke's reimagining of automobile campgrounds relied on the adoption of modern techniques. Nevertheless, his approach resulted in a workable, widely accepted and enduring feature in the landscapes of protected areas in the United States of America.

\section{Camping, Pilgrimage and Modernity}

Camping as a form of American recreation was not new in 1932, having begun in earnest during the immediate post-Civil War period. Sport hunters and anglers had long camped to support their recreational pursuits, but after a Boston clergyman, William H.H. Murray, wrote Adventures in the Wilderness; or, Camp-Life in the Adirondacks in 1869 , camping came into its own. This guidebook, which was simple, clear and practical, was also the first to engagingly explain why one camped, how one did so, and where one went. Adventures in the Wilderness was an immediate best-seller, sent thousands of novice campers into the Adirondacks, and according to one scholar, "exerted a lasting influence upon outdoor recreation in America" (Cadbury, W, 1989: 11)

5 Murray's book launched recreational camping in the United States because of its style and substance but also because it appeared as Americans began to wholeheartedly embrace modernity. A notoriously challenging concept, modernity refers to the historical period when capitalism, industrialization, rationalization and related institutions transformed more traditional societies into "modern" ones. According to sociologist Anthony Giddens, modernity is "vastly more dynamic than any previous type of social order [and] unlike any preceding culture, lives in the future, rather than the past" (Giddens, A, 1998: 94). Unsurprisingly, the consequences of modernity have been pervasive and taken many forms, including a reorganization of settlement patterns. $^{2}$

6 America had been historically an agrarian society of small towns, so the modern shift toward urban life, industrial capitalism, and the future left many Americans unsettled and distressed. When rural residents moved to cities they often found abundant opportunities, but also smoke, noise, crowding, social diversity, production schedules, regulation and more. In response to this rapid transformation, a variety of now common phenomena emerged, including camping, which was rural and wildland oriented, anti-modern, and focused on the past and its practices. ${ }^{3}$ According to Murray (and many subsequent camping proponents), urban dwellers were wise to regularly retreat into the wild because of the "total absence of [modern] sights and sounds and duties, which keep [one's] brain and heart strung up, the long year through, to an intense, unnatural and often fatal tension." In contrast, nature provided "many beauties [...] to the gazer's eye," "restore[d] impaired health," and offered "that perfect relaxation which all jaded minds require" (Murray, W., 1989: 11, 22). We can see today 
that even though Murray never declared it to be the case, he was offering camping as a pilgrimage to nature.

7 This judgment may seem jarring, but in its simplest form, a pilgrim is someone who leaves home, journeys to a sacred place as an act of devotion, and returns home changed. Pilgrimage need not be a religious act. Pilgrims' personal motivations vary, but they typically seek escape from the routine and restrictions of ordinary life, often in places that are historically and culturally significant, in order to find spiritual, physical and other forms of satisfaction and comfort. In addition, pilgrimage is generally arduous, forcing a pilgrim to endure physical, emotional and other challenges as a part of the journey (Turner, $\mathrm{V}$ and Turner, E, 1978). ${ }^{4}$

While camping is certainly not a religious practice, it has shared in this pilgrimage pattern. For much of its history, Americans have referred to camping as "roughing it" because campers traditionally have shed many domestic conveniences. Like other pilgrims, campers have perceived great power at a place - "nature" - which was often overtly linked to the "frontier" and "pioneer" past of the USA. When camped at, such places could counteract the "evils" of modern, urban life and "restore" them mentally and physically. And, since all pilgrimage is an internal as well as external voyage, the transformation had to be initiated by the camper and it would occur only if he or she traveled to where nature's power was perceived as readily accessible; not just any outdoor location would do. Consequently, not all campers have journeyed to the same destination. Nevertheless, all have felt they were camping.

Even though American camping arose as a reaction against urban-industrial life, it was not beyond the reach of modernity. In order to understand how modernity alters society, another sociologist, George Ritzer, developed the notion of "McDonaldization," which is "the process by which the principles of the fast-food restaurant are coming to dominate more and more sectors of American society as well as the rest of the world." McDonaldization occurs, Ritzer argues, because "it offers consumers, workers, and managers efficiency, calculability, predictability, and control." Efficiency refers to the identification and employment of optimum methods for completing tasks. Calculability plays up a service or product's quantitative aspects. Predictability means that "products and services will be the same over time and in all locales." Consumers can take comfort in the fact that when they make a purchase, no surprises will occur even as producers can rely on the regularity of their systems, which allows them to forecast rates of output. Finally, Control is exerted over everyone who participates in a system. In particular, methods are employed that will lead participants to do what management wishes and when. McDonaldization has a history stretching back to the beginnings of modernity, it has long been widespread throughout American society, and it modified camping in fits and starts (Ritzer, G., 2008: 1, 13-14).

Modernity began to alter camping early in its history because not every camper wanted to experience a maximum of roughness. Instead many sought greater control and comfort, which led equipment manufacturers to quickly develop new products to reduce or remove various camping challenges. Sensing a consumerist desire to "smooth out" camping's adventures, "improved" versions of tents, sleeping arrangements, stoves, cookware, lighting devices and myriad other forms of "gear" became available (Figure 1). Moreover, the new items were often produced and sold in standardized versions, which reduced production costs and potentially provided manufacturers with 
greater profits and a larger market share. But equipment consumption and production were not the limits of McDonaldization. Nature and its spaces can also be modernized.

Figure 1. Equipment manufacturers rapidly developed new products aimed at reducing camping's "roughness."

Here a standardized, relatively light set of cooking and dining materials could be nested into a small space during transport yet were capable of serving the needs of six campers.

From Horace Kephart's Camp Cookery (1910)

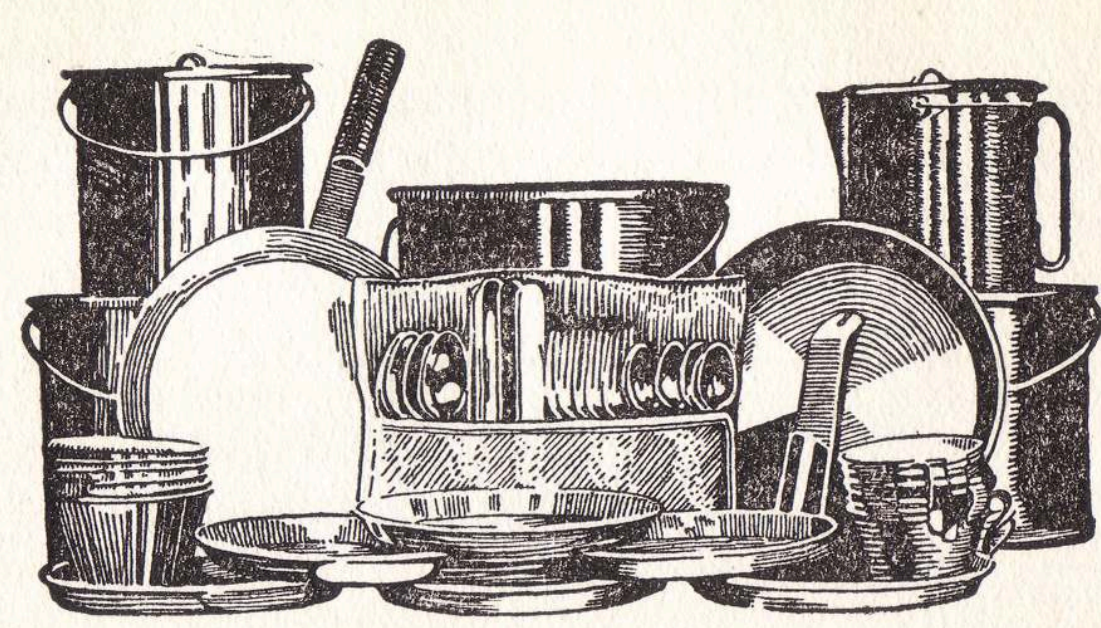

Cooking Kit for Six.

Nesting in space $11 \times 12 \% / 8$ inches, and weighing $171 / 4 \mathrm{lbs}$.

\section{The Automobile Appears and Protected Areas Suffer}

11 The array of increasingly specialized, McDonaldized gear expanded for 40 years after the 1869 appearance of Adventures in the Wilderness, but at the dawn of the twentieth century, relatively few Americans had taken up camping. Only a minority of middle to upper-middle class Americans enjoyed it because the equipment remained bulky and heavy despite refinements. However, the situation changed rapidly during the $1910 \mathrm{~s}$ and 1920s as the number of campers jumped from only 300,000 in 1915, to more than $3,000,000$ by 1930 . The primary cause for this skyrocketing growth was one of modernity's premier symbols - the automobile (Figure 2). Cars made it possible to reliably and conveniently carry a family plus large amounts of equipment and supplies over great distances. Once they became inexpensive and within the reach of workingclass families, the number of autocampers exploded (Statistical History, 1965: 222).

Figure 2. A well-equipped family of autocampers during the $1920 \mathrm{~s}$.

From Frank E. Brimmer's Motor Campcraft (1923) 


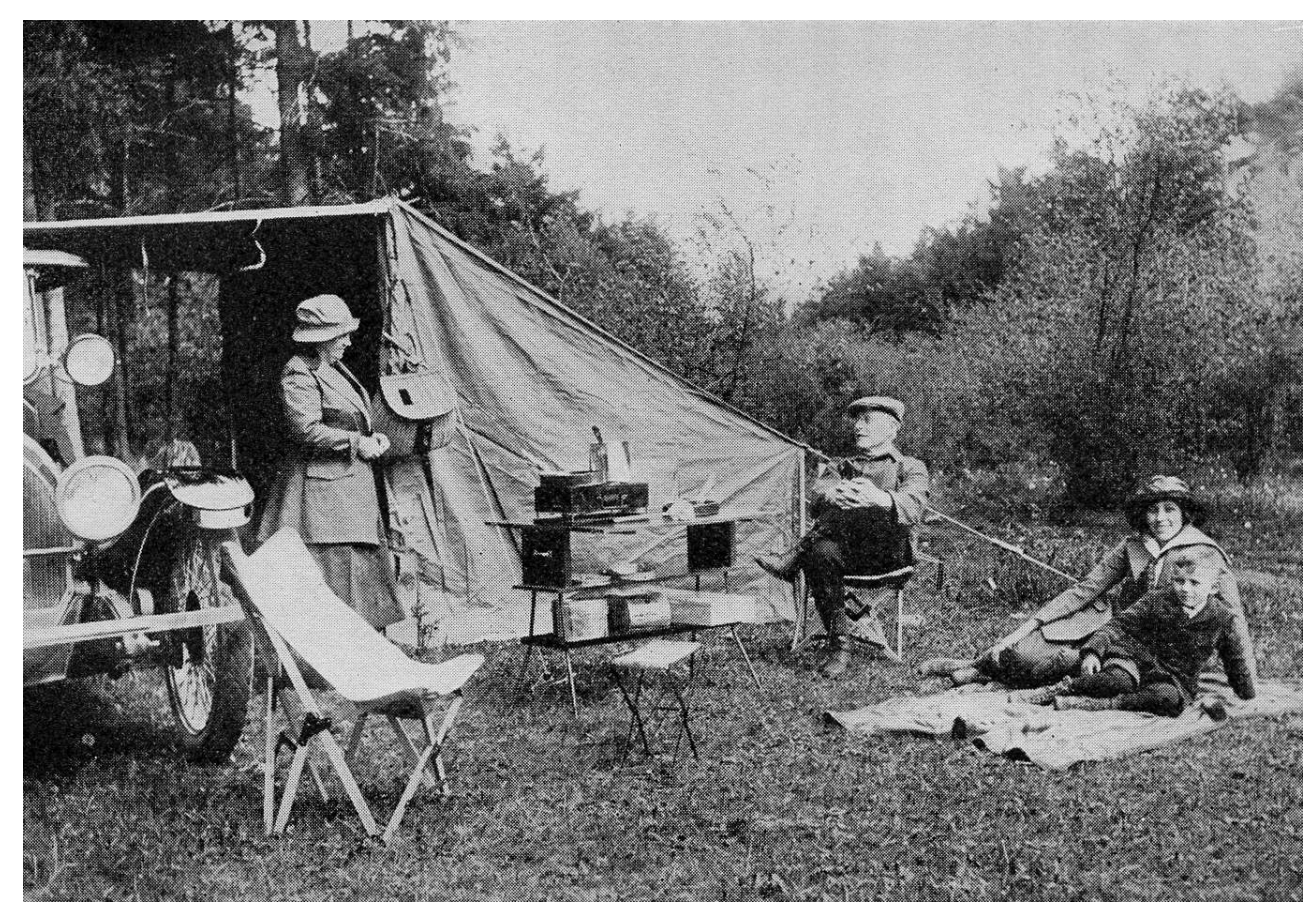

But the quality of many destinations deteriorated under this deluge of enthusiasts because camping was virtually unregulated in the United States of America's protected areas. It had arisen as an anti-modern, nature-based anodyne for the growing regulation and constraints of urban life, so camping rules and restrictions were seen as contrary to its "frontier spirit." Consequently, unlimited numbers of autocampers were typically free to set up their equipment haphazardly at any accessible public location (Figure 3). In these chaotic conditions, crowding, noise, pollution, and vegetation loss were common. By the late 1920s, public campgrounds nationwide were being abandoned as degraded and unappealing, so park and forest authorities turned to E.P. Meinecke, whose McDonaldizing prescriptions would correct the worst of these conditions (McClelland, L., 1998: 277). Meinecke's recommendations, however, contained a touch of irony because even as they modernized the camping experience, they remained focused on the anti-modern pursuit of nature.

Figure 3. Stoneman Meadow, Yosemite National Park.

Autocampers were free to move and camp virtually anywhere through the 1920s, which resulted in widespread environmental damage.

US National Park Service. 


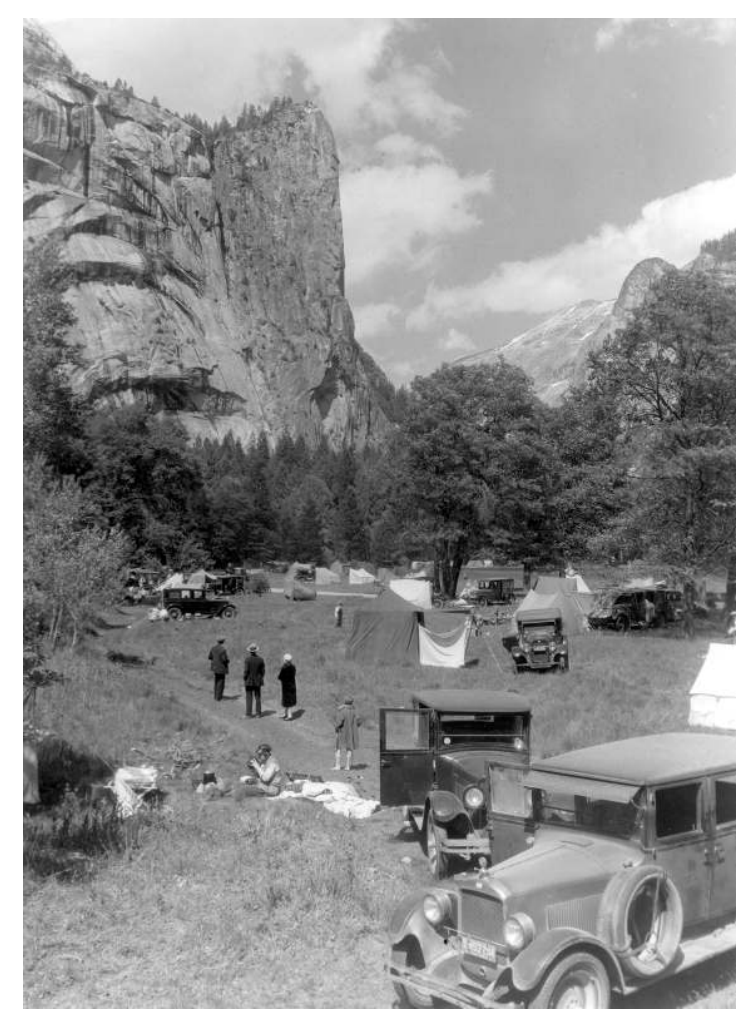

\section{E.P. Meinecke Offers a Prescription}

E. P. Meinecke (Figure 4), widely known as "Doc," was born in Alameda, California in July 1869. His German parents and grandparents had arrived early to American California and had prospered in the hurly-burly of those years. When a boy, Meinecke moved to Germany where his parents had him remain for an education that ultimately included university studies and an 1893 doctorate in botany from Heidelberg University. Following graduation, Meinecke worked as a researcher and an instructor in Germany and Argentina, but in 1909 he decided to return to California. Shortly after returning to the San Francisco Bay Area, Meinecke participated in a US Forest Service (USFS) ranger school where he met many foresters and left a favorable impression. As a result, Meinecke was soon asked to join the San Francisco office of the US Department of Agriculture's Bureau of Plant Industry (BPI) as a consulting forest pathologist to the USFS's District 5 (California) (Baker, F., 1948; Wagener, W., Hartley, C., and Boyce, J., 1957; and, San Francisco Examiner, 1957).

Figure 4. "Doc" Meinecke around 1928. 


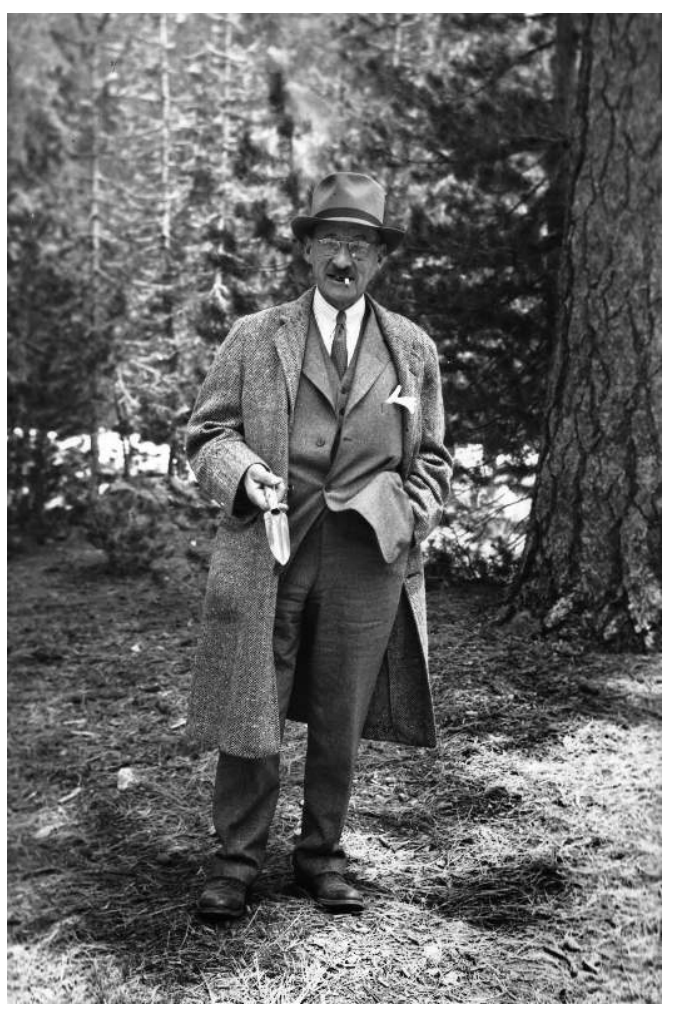

For his first 16 years with the BPI, Meinecke focused professionally on trees damaged by insects, diseases and other natural pests, but in fall 1925 the Director of the National Park Service (NPS), Stephen Mather, approached the USFS District 5 Forester, Paul G. Redington, for assistance with Sequoia National Park where visitors were causing injuries to the Sequoia gigantea, or "Big Trees." How, the Director asked, can we mitigate the negative impacts of "intensive camping and heavy foot traffic" at the most picturesque tree groves? Redington had no ready answer so he referred Mather's query to Meinecke who, intrigued, visited the park in May 1926. He discovered a grossly imbalanced and dire situation. The public, Meinecke warned in a 19-page report, were loving the trees to death. "One of the deplorable consequences of camping and long continued milling of tourists around selected favorite [trees]," warned Meinecke, "is the almost complete eradication of undergrowth." Furthermore, in a zone adjacent to the biggest trees, the most important and active roots were being destroyed by the simple act of walking. His recommendation was that park authorities adopt measures to counteract past injuries and degradations as well as modernist policies that would control visitor movements and prevent new damage. However, Meinecke urged, these measures and policies should not be "direct" ones because visitors primarily came from cities to escape modern life's regimentation and to immerse themselves in nature as an act of devotion. As a consequence, "both remedial and preventive action," he counseled, "must be predominantly indirect." "Keep Off" signs and similarly direct measures would remind visitors too much of the unsettling, everyday world that they had recently escaped, but an impeding pile of wood or stones could control visitors without directly ordering them about. With "indirection" as a guiding principle, Meinecke recommended that the compacted zones be reforested with Sequoia gigantea and that any camping area situated under a Big Tree be abandoned. Park personnel heeded Meinecke's advice and rapidly began the removal of campgrounds from around Big Trees and to replant the forest (Meinecke, E., 1926: 2, 10, 11-19). ${ }^{5}$ 

assess the forest and camping situation in California's several state parks where Redwoods (Sequoia sempervirens) were protected. Unsurprisingly, his 1928 report detailed deteriorating conditions like those at Sequoia National Park. Autocampers and other visitors had trampled uncontrolled across the state parks' landscapes leaving "wide areas [...] completely bare of vegetation" and soil compacted "to the marked and serious detriment of the roots." The physical setting of the trees clearly needed to be addressed, but Meinecke again cautioned that any changes should be guided by the public's anti-modern embrace of the Redwoods themselves. "To some," he noted, Redwoods "are objects of wonder and amazement, unique in size and age. To others they offer ideal surroundings for a pleasant outing and camping. To a third group the rare beauty of the parks will make the strongest appeal. Still others will find spiritual uplift and emotion. All of these attitudes, which frequently may overlap, spring from cultural sources, and all of them must be recognized in any well-reasoned policy of use in the Parks." In effect and without directly stating it, Meinecke recognized that autocampers were pilgrims seeking connections they could not make in everyday urban places. However, the unregulated use of the state parks had led to environmental damage. Nevertheless, the path forward was clear for Meinecke. Future management had "to make traffic subordinate to the welfare of the trees and to eliminate all features which are likely to have an ill effect either on their health or on the beauty of the landscape" (Meinecke, E., 1928: 8, 11-12).

With both physical and cultural goals in mind, Meinecke offered four recommendations that blended modern methods with anti-modern sensibilities. First, managers needed to exert control over conflicting park functions by spatially segregating them from each other. The Redwood groves, which visitors found most appealing, needed to be managed differently than other park areas. Deeply symbolic and richly anti-modern, they should predictably foreground the trees while downplaying any fences, paths or other artificial features deemed necessary. Enhanced vegetation protection would result, but the principal product would be an improved visitor experience through an enhanced sense of place. "The main groups of Redwoods," Meinecke offered, will "resume the rank they held before a heavy and uncontrollable invasion tended to cheapen their prodigious beauty in the eyes of the public." McDonaldization would enhance the appeal of Redwood groves as sacred places (Meinecke, E., 1928: 13).

Second, Meinecke relatedly noted that camping areas tended to suffer the worst soil compaction so he again recommended that authorities exert spatial control. Camping, he declared, should be "absolutely banned from the main [Redwood settings] and concentrated in the marginal areas [where] it can do little harm." Third, Meinecke took aim at the spatially unregulated and destructive movement of pedestrians when he advised that controlling trails and paths be established through Redwood groves and the public trained to stay on them. Such constraints and training, however, had to be handled sensitively and indirectly. In a city park, signs and fences might be appropriate, but, Meinecke warned, "both are distinctively objectionable in the atmosphere of the Redwood parks and should be used only as an ultimate resort." Instead, state park managers should take an indirect, naturalistic approach, where the look and location of controlling features would be subordinate to and harmonize with the natural environment. Meinecke suggested that a carefully placed log, fallen limb, or rock, or a thoughtfully planted shrub "serves as well as a solid fence." Finally, Meinecke 
recommended that trampled areas be restored, but again he went beyond any strictly botanical issues to express a concern that any restoration appear "natural" to autocampers and other visitors. "Unless this is done with great skill the effect will be one of artificiality and consequently undesirable" (Meinecke, E. 1928: 13-15).

Meinecke's embrace of park zoning and naturalistic tools to control visitor movements demonstrate his emerging preference for modern spatial strategies sensitive to the anti-modern sensibilities of autocampers. Henceforth, Meinecke's recommendations would manipulate the links between vegetation, space, and landscape design in order to both foster the camping experience and curtail its environmental damage.

Meinecke's insightful and practical reports of 1926 and 1928 were widely read by US park and forest managers, prompting many to contact him for assistance. Additional successful consultations followed and in May 1931 Meinecke added a new assignment to his BPI responsibilities - "Consulting Pathologist" to the entire national park system. In his expanded capacity, Meinecke consulted frequently on forest disease issues, but he also spoke at a variety of professional meetings about protected area campgrounds. These facilities, he generally argued, tended to be unregulated, progressively damaged, and consequently abandoned for new ones, which subsequently suffered the same fate. This wasteful practice needed to end. Instead of disorder and abandonment, he prescribed a well-considered policy on campgrounds and a system for their rotation. However, it was not until early 1932 that he settled on an approach to the problem and produced the automobile campground plan that soon became, and long remained, the model for parks and forests throughout the United States of America (Albright, H, 2016: $81-82){ }^{6}$

\section{Campground Deterioration}

E.P. Meinecke's comprehensive campground plan apparently began to take form during summer and fall 1931. As he consulted at national parks and forests, he increasingly found himself being asked about campground damage. The problem was growing more stark and the supervisors responsible to address the issue hungered for solutions. Meinecke did not leave an account of his personal deliberations and thoughts, but in late March 1932, he presented a well-received paper about campgrounds at a USFS supervisor's conference in San Francisco. In short order he revised it into what would become his most momentous report, "A Camp Ground Policy," and presented a mimeograph copy of it to the Forest Service on April 2, 1932 (Meinecke, E., 1932c, Meinecke, E., 1932b). ${ }^{7}$

21 Like Meinecke's earlier prescriptions, A Camp Ground Policy offered a tense balance between modern and anti-modern. On the one hand, Meinecke McDonaldized many previously haphazard elements common to campgrounds. On the other hand, he foregrounded the anti-modern aspects of camping and the need for a naturalistic campsite. Unsurprisingly, the report began by focusing on vegetation loss, but instead of being concerned about pedestrians, Meinecke fixed on automobiles, which he argued were camping's greatest hazard. "The automobile has brought new and serious complications," he warned, because in unregulated situations, they compacted soil, broke branches, stripped bark from trees, and poisoned the earth with motor oil. "A single invasion of a new camp site by an automobile would soon be repaired," Meinecke admitted, but that was unlikely in a public campground where autocampers regularly 
came and went for months. "It is the constant repetition of the injurious action, day after day, year after year, that ends in disaster, and the final result is the destruction of the elements that make a certain locality suitable for camping" (Meinecke, E., 1932a: 2).

In Meinecke's view, most protected area managers had wisely exerted control over autocampers by designating specific areas for them, but then committed a crucial error. They provided no guidance or rules about where to set up camp within the campground. This lack of internal regulation allowed the initial autocampers in a new campground to determine which locations were "best." These autocampers caused minor harm to the natural environment themselves, but a disastrous pattern had been set. After a site was selected by the first autocampers, subsequent ones literally followed in the same tracks and their use compounded and expanded any damage done previously. As each successive camping party entered and departed, Meinecke observed, "automobile tracks are widened and new ones added." As time passed, "more ground is cleared and more trees wounded." These repeated injuries killed a tree sooner or later and once it became "unsightly," it soon would be cut down. The loss of these trees, what Meinecke termed "key trees," was decisive. As a key tree was lost, the size of the remaining tree groups within and near a camp site would shrink as each loss exposed the next tree into a group to moving autos (Figure 5). This inward tree now became the key tree and the disastrous process would repeat itself until only the largest, most indestructible trees survived. (Meinecke, E., 1932a: 2) (Figure 6).

Figure 5. E.P. Meinecke's illustration of an unregulated campsite.

"Note," he directed, "the waste of space and the steady whittling of the Keys A, B and C and the ensuring recession of the groups."

From 1932's A Camp Ground Policy.

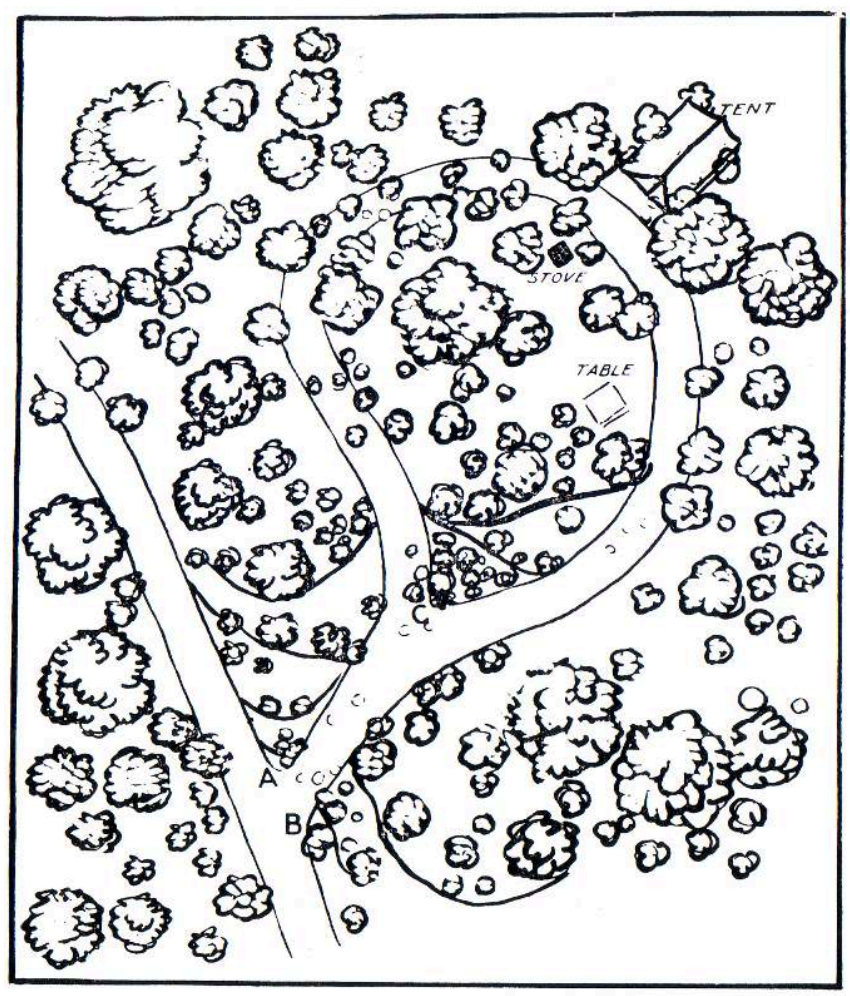


Figure 6. E.P. Meinecke's example of a "Camp Ground ruined by uncontrolled use".

Tree stumps were all that remained of vegetation.

From 1932's A Camp Ground Policy.

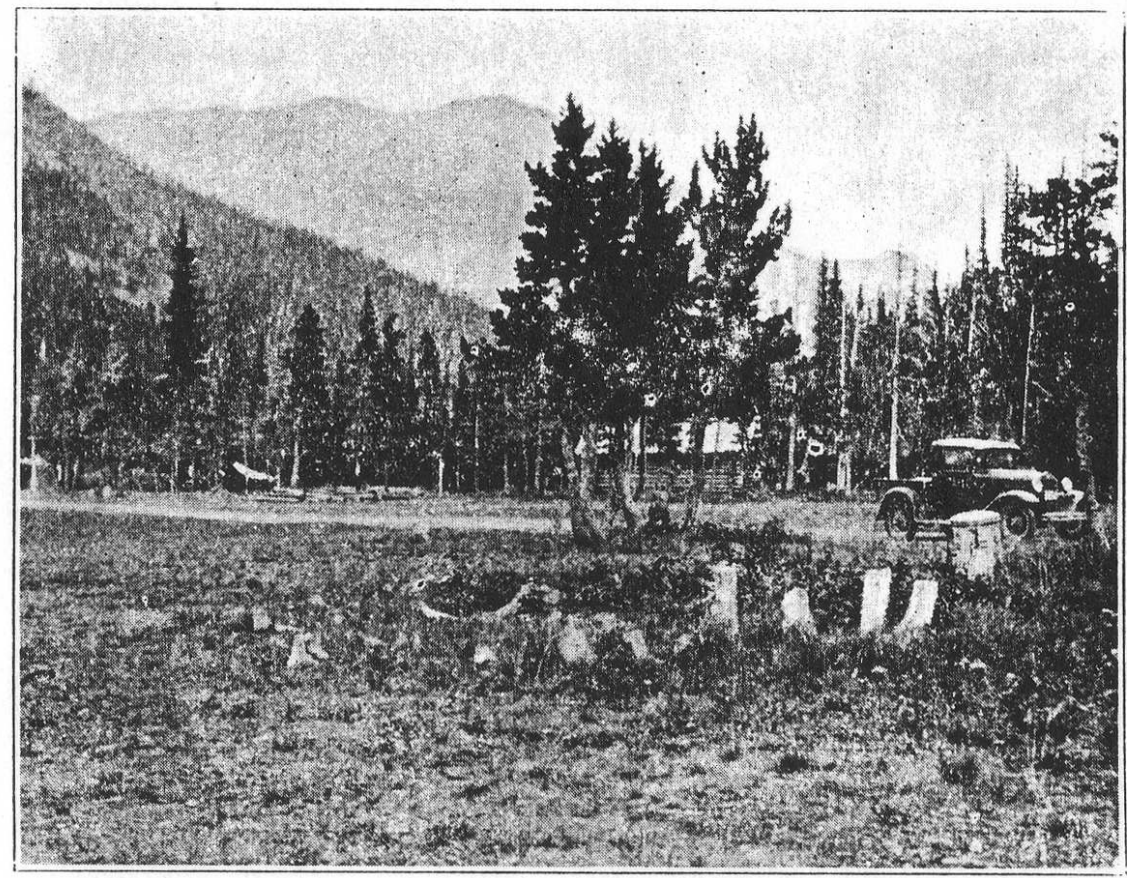

But automobiles were not Meinecke's only concern. "The campers themselves" were a menace because they would "break through young growth and open up the groups." In particular, they chopped down trees for firewood and to allow ease of movement. Their walking about, which tended to cover more and more ground as an unregulated campsite expanded and deteriorated, also trampled low growing vegetation and compacted soils. And, of special concern to the pathologist, were the accumulating and toxic campfire ashes left behind. Since it was "unpleasant to cook while standing in the scattered ashes of an old one," people constantly chose new sites for their campfires. In one of California's Sierra Nevada campgrounds, he noted sadly, were "no less than 43 ash heaps from four to five feet in diameter [...] on a piece of land not larger than one quarter of an acre." As a consequence of these compounding negatives, an unregulated campsite steadily deteriorated and would eventually be "rendered undesirable for the more appreciative class of tourists" (Meinecke, E., 1932a: 4-5).

In addition to the environmental damage caused by unregulated autocamping, Meinecke was annoyed and concerned about its "great waste in space." Spatial inefficiency resulted because haphazard autocampers kept pushing a campsite's boundaries outward. Such spatial consumption had to cease. "In certain part of the country conditions have already reached a point where the administrator in charge is hard put to accommodate the steadily growing influx of campers." Many campgrounds were either deteriorated or about to be abandoned with no alternatives available. What did all this mean for the public lands administrator in charge of campgrounds? The public, Meinecke ominously warned, will not accept explanations if it is "denied what it has come to consider as its rights." You have a serious problem, he told campground 
managers, which is about to explode in your face, but there is a solution (Meinecke, E., 1932a: 7).

\section{Meinecke's Solution}

If, Meinecke posed, the primary cause of campground damage was the lack of regulation, then the solution, one which mimicked the domestic spaces of everyday life and which radically McDonaldized the campground, was obvious. "The choice of camp sites within a designated camping ground and the physical arrangement can no longer be left to the tourist." Their choices and movements were unpredictable and inevitably led to ruin. Instead, he urged, campground arrangement had to be "planned in advance, and the plan must be rigidly adhered to." Administrators, Meinecke insisted, had to begin exerting control over their campgrounds. Local plans would have to be guided by such variables as topography, vegetational cover and climate, but in keeping with his previous prescription, control had to be primarily spatial (Meinecke, E., 1932a: 8).

At the same time, Meinecke recognized that campground administrators might be concerned that regulations would prompt autocampers' anger, but governing them would not be particularly difficult, Meinecke reassured, if the general character of autocampers and the goals of camping were kept in mind. "The average tourist is willing to conform, according to his understanding, to what he is supposed to do in the forest." Autocampers were not rugged, individualistic adventurers seeking true challenges in unknown situations. Instead, the autocamper was a "city man" who was "amenable to suggestion, and, in general acts as he thinks others have acted before him." Therefore, Meinecke pointed out, it was extremely important to plan "a camp in such a way that no doubt is left as to the behavior and the reactions that one expected of him." With this reality in mind, Meinecke again offered a four-point plan that would deliver efficiency, calculability, predictability and control while satisfying an autocamper's urge to depart the everyday life. In other words, a modernized place for anti-modern retreat (Meinecke, E., 1932a: 9).

First, managers needed to evaluate their entire campground in order to divide it into "individual camp sites of legitimate size, [with] each one offering approximately as much privacy, shade and other advantages as the other." If thoughtfully and carefully executed, each resulting campsite would be predictably alike and provide similar satisfaction to every autocamper. In addition, each camp site had to "clearly appear as a unit at first glance." Ideally, there would be no doubt in the mind of a newly arrived autocamper about the position and limits of each campsite. To reinforce the calculability of each campsite, Meinecke also recommended that each be given "a number or other designation." These addresses transformed the identification of individual sites from relative and positional differences into objective, quantifiable ones. The site "at the back of the campground near the large rock" became "campsite six." This numbering, Meinecke suggested, would also make administration more efficient by easing "the assignment of definite camp sites to visitors." The manager who knew that a campground contained only 26 units, had greater control than in an unregulated situation because it was now possible to tell a $27^{\text {th }}$ visitor that the campground was full (Meinecke, E., 1932a: 10-11). 

d, every camp site needed to incorporate three elements - a fireplace (also called a stove), a camp table, and a location for the tent. The initial item to consider was the iconic fireplace, which while practical was also ingrained in camping's rituals and which "determines the physical arrangement of the outdoor home" (Figure 7). The fireplace had to sit where it would not damage the vegetation and where winds would "assure a good draft." Then, once positioned permanently, "the camp table will always find its place nearby, and the tent will not be far removed." Fixing the fireplace was not a new idea, Meinecke admitted, but it was a timely one. "Permanent stoves or simple contrivances [...] in solid concrete" were an improvement over campfire rings because the former allowed for the control of toxic, residual ashes. Moreover, fireplaces were large, heavy, and "cannot be moved," which meant the other elements were not likely to be moved either. As an added bonus, when every element was predictably present and conveniently arranged, then an autocamper was more likely to feel that she was having a satisfying experience. Remember, Meinecke noted, "So long as the placing of the main features, relative to each other [...] is logical and practical the camper will have no incentive for a rearrangement." As a consequence, the paths within each campsite would be limited to the connecting lines between car, fireplace, tent and camp table only. "The disorderly and destructive tramping about, that characterizes the unregulated camp, is obviated since there is no need for it" (Meinecke, E., 1932a: 11-12).

Figure 7. A typical fireplace or "stove" used in a US national park during the 1930s.

Meinecke considered fireplaces to be a central feature of his design because they were immovable and wood ash could be removed easily for proper disposal elsewhere.

From US National Park Service.

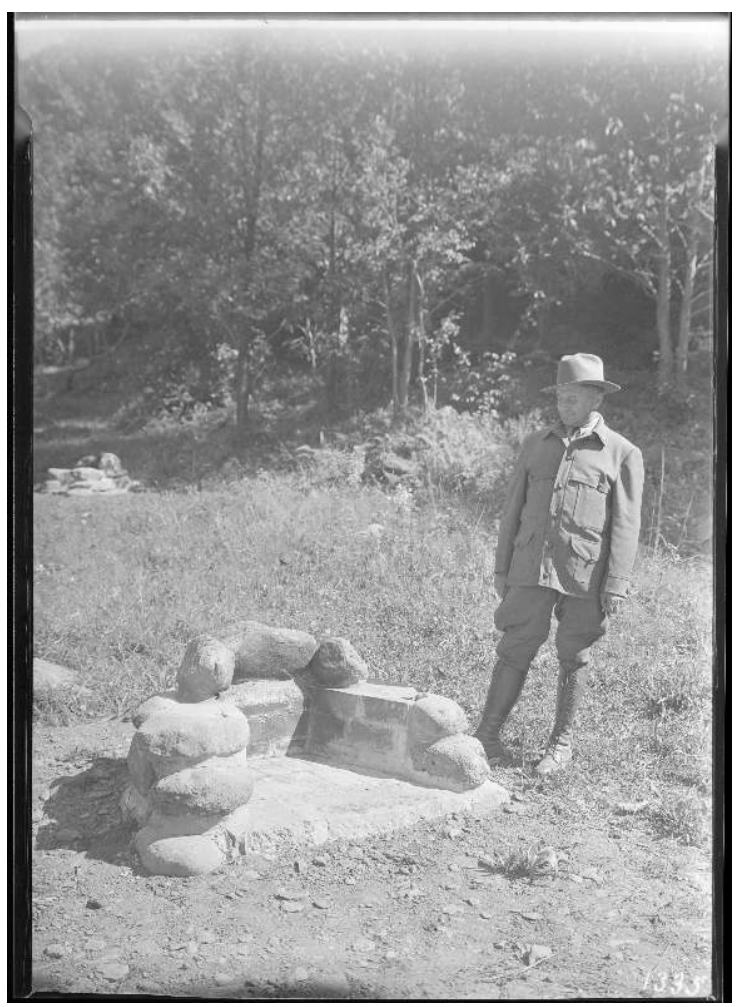

Having identified and offered his prescription concerning the three key elements of a campsite, Meinecke turned to the automobile as the third point of his overall plan. 
Since camping would be restricted to designated campsites, each one needed to be automobile accessible without causing random environmental damage within the larger campground. Moreover, it had to be an efficient use of campground space. Therefore, Meinecke argued, "the regulated camp ground should be provided with roads [and] in the interests of space economy that they be one-way roads." In addition to being space efficient, one-way roads were narrow, which meant they offered "less chance for breaking out into untouched vegetation" and they could easily be added onto when demand increased (Meinecke, E., 1932a: 11) (Figure 8).

Figure 8. E.P. Meinecke's illustration of a campground properly laid out with an expandable system of one-way roads.

From 1932's A Camp Ground Policy.

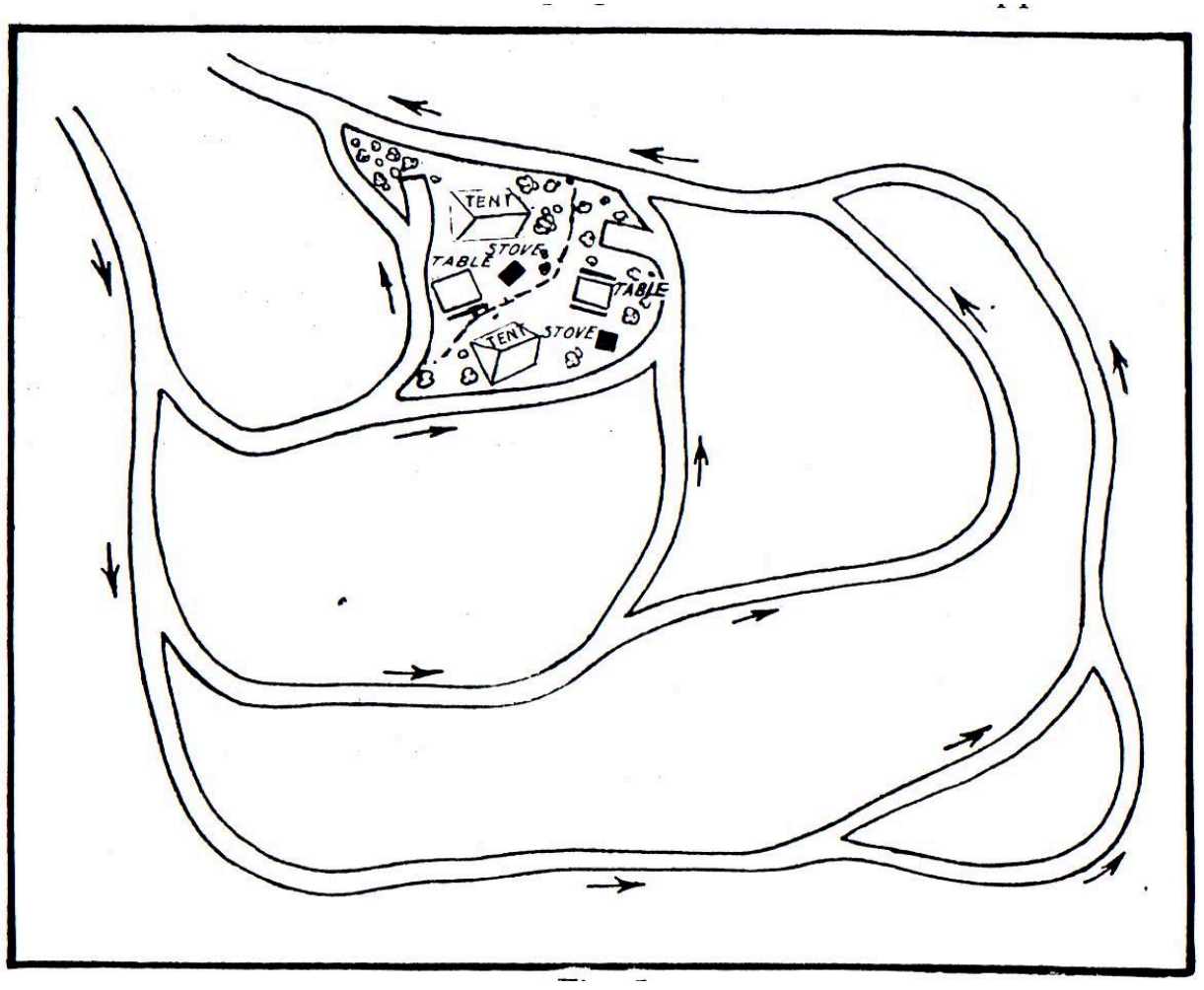

The roads, in their turn, made possible the fourth and "essential feature of the plan" the "garage spur." Since a moving automobile was "the most destructive element" in any campground, it had to be "fixed at the entrance to the camp site and not be permitted to enter the latter at all." The solution was simple, announced Meinecke. Every campsite needed to include this element from modern urban life - "A definite garage in the shape of a short spur leading off at a suitable angle from the one-way road" (Figure 9). And, cautioned Meinecke, it was crucial that this feature "be plainly marked." A newly arriving autocamper had to be able to immediately recognize garage spurs for what they were. A light touch and ambiguity would not be a virtue in this situation because they might encourage autocampers to drive into and between campsites. Instead, a spur should be "cleared of vegetation, and at strategic points rocks" should sit to clearly indicate its boundaries. How were authorities to keep autocampers from simply moving their cars elsewhere in the campsite? By using "the tourist's desire to protect his property, particularly his car, from injury," instructed Meinecke. At critical points along a campground's roads and around every campsite's 
spur, obstacles "sufficiently heavy so as not to invite moving by the average camper, are placed in such a way that, in self-preservation, the camper will not drive over them." Again he emphasized a harmonizing, indirect approach by promoting the use of logs, boulders and similar objects to constrain automobile movement. The outcome Meinecke promised would be a reduction in vegetation loss and a more space efficient campground with increased capacity. Two of his campsites would be able to occupy the space of a single unregulated one (Meinecke, E., 1932a: 9, 11).

Figure 9. E.P. Meinecke's illustration of "regulated development on a newly laid out camp ground".

It demonstrates his system of "garage spurs" and sites for tables, stoves and tents. The illustration represents "identically the same unit of land" as in Figure 5, which contains only one campsite where this one includes two.

From 1932's A Camp Ground Policy.

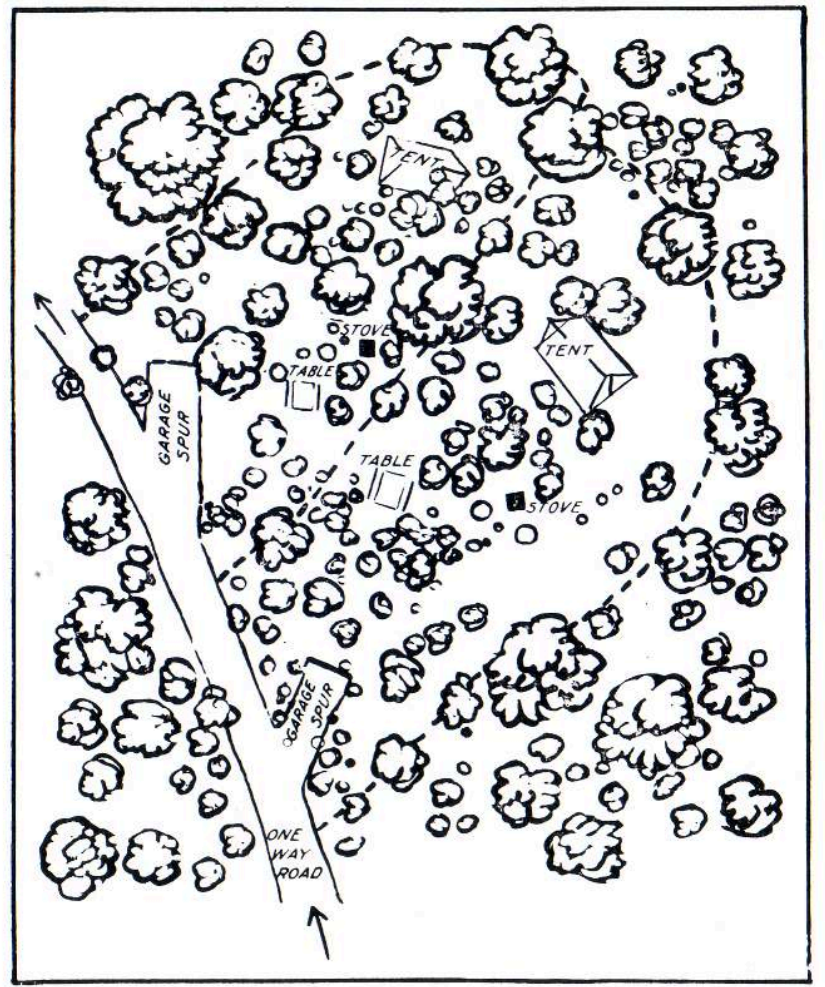

With the four principal points of his plan laid out, Meinecke noted that one interlacing element remained - all the campground vegetation not previously addressed in the plan. Obviously, he admitted, some trees and shrubs would likely end up in the way as any Meinecke-inspired plan was executed. An administrator could leave these plants to be removed by autocampers, but that would set a bad precedent. "It is better," suggested Meinecke, "to remove, beforehand, the shrubs and trees" that were going to interfere with autocampers because of the psychological impact. Instead of leaving plants where they might be "annoying," they should be removed by authorities. On the one hand, this act of environmental control would promote a satisfying camping experience because thoughtfully cleared campsites were likely to "set up a reaction of contentment in the camper's mind." On the other hand, the removal of interfering and irritating trees and shrubs would "foster a respect for the [remaining] plant growth that makes [someone's] camp site a livable and pleasant place at which to stay" (Meinecke, E., 1932a: 12). 

camping and natural landscape. Autocampers typically wanted "green and shady campsites," but he cautioned, they would not be easy to satisfy because they unconsciously held two conflicting views about campgrounds and the camping experience. The average autocamper, who came from relatively close quarters in the city, "does not feel at home in what to him is wild country in the relative isolation of the forest." Autocampers were accustomed to the modern world's conveniences, little wildlife, and many nearby neighbors. As a consequence, "he prefers the semidomestication of nearby camps, easily reached and easily left." At the same time, autocampers fled the modern world in order to be released "from the restrictions of town and city." That is, an autocamper was acting like a pilgrim who headed out of her or his everyday world on a journey into restoring nature. Therefore, concluded Meinecke, the planting and maintenance of campground vegetation, like the constraining objects around a garage spur, had to be pursued sensitively and "in close imitation" of nature. Remember, he cautioned, "Landscaping in the usual sense," that is direct, as in a city park, "has no place... where the visitor seeks at least the illusion of wildness" (Meinecke, E., 1932a: 9, 12, 14).

The US Forest and National Park Services promptly embraced Meinecke's proposal. NPS Director Horace Albright ordered a copy of the original oral presentation to be read at the park superintendents' conference in Hot Springs, Arkansas on April 4, 1932. Before the next week was out, the USFS Regional Forester for California, SB Show, also requested that mimeographed copies of the presentation be sent throughout the region "as soon as possible" and he informed Meinecke that his office planned to make the proposals "standard requirements for the region." And, during the same week, Meinecke marveled, "Requests for copies have come from a number of men all over the country" (Meinecke, E., 1932c). By July, hundreds of mimeographed copies had been sent to national forests and parks across the United States, leading Meinecke to bemoan the consequent wave of requests for his advice while he sat typing in Honolulu. As fall rolled around, thousands of both mimeographed and printed copies had been distributed throughout both services and, in the words of historian Linda Mcclelland, "major changes began to appear in the[ir] campgrounds" (McClelland, 1998, 281).

many subsequent autocampers and campground managers, a Meinecke-style layout resulted in an enhanced experience. In July 1933, the first full summer after the publication of A Camp Ground Policy, the Chief Ranger at Sequoia National Park reported that he was most pleased with the results of their newly re-arranged campgrounds. A significantly larger number of autocampers had stayed over the July $4^{\text {th }}$ holiday, but "there was far less crowding, confusion and almost negligible damage to vegetation." of course, it is easy to understand why a design that produced enhanced crowd control, less chaos and greater environmental protection should appeal to this administrator, but Sequoia's autocampers approved the change too. According to the Chief Ranger, "the camp patrol Rangers have heard many compliments about less crowding and more system" (White, J., 1933).

35 As more and more forest and park authorities embraced Meinecke's approach it was officially incorporated into the NPS's Park Structures and Facilities, a widely distributed, 1935 guide to park architecture and again in the NPS's Parks and Recreation Structures of 1938 (Good, A., 1935, Good, A. 1938). Over the next several decades, public campgrounds nationwide came to incorporate defined roads, designated campsites, garage spurs, and 
controlling obstacles to protect vegetation (Figure 10). Today Meinecke-style campgrounds can be found throughout the protected areas of the United States (Figure 11).

Figure 10. A new, Meinecke-style campsite in Grand Canyon National Park in May 1934.

US National Archives and Records Administration.

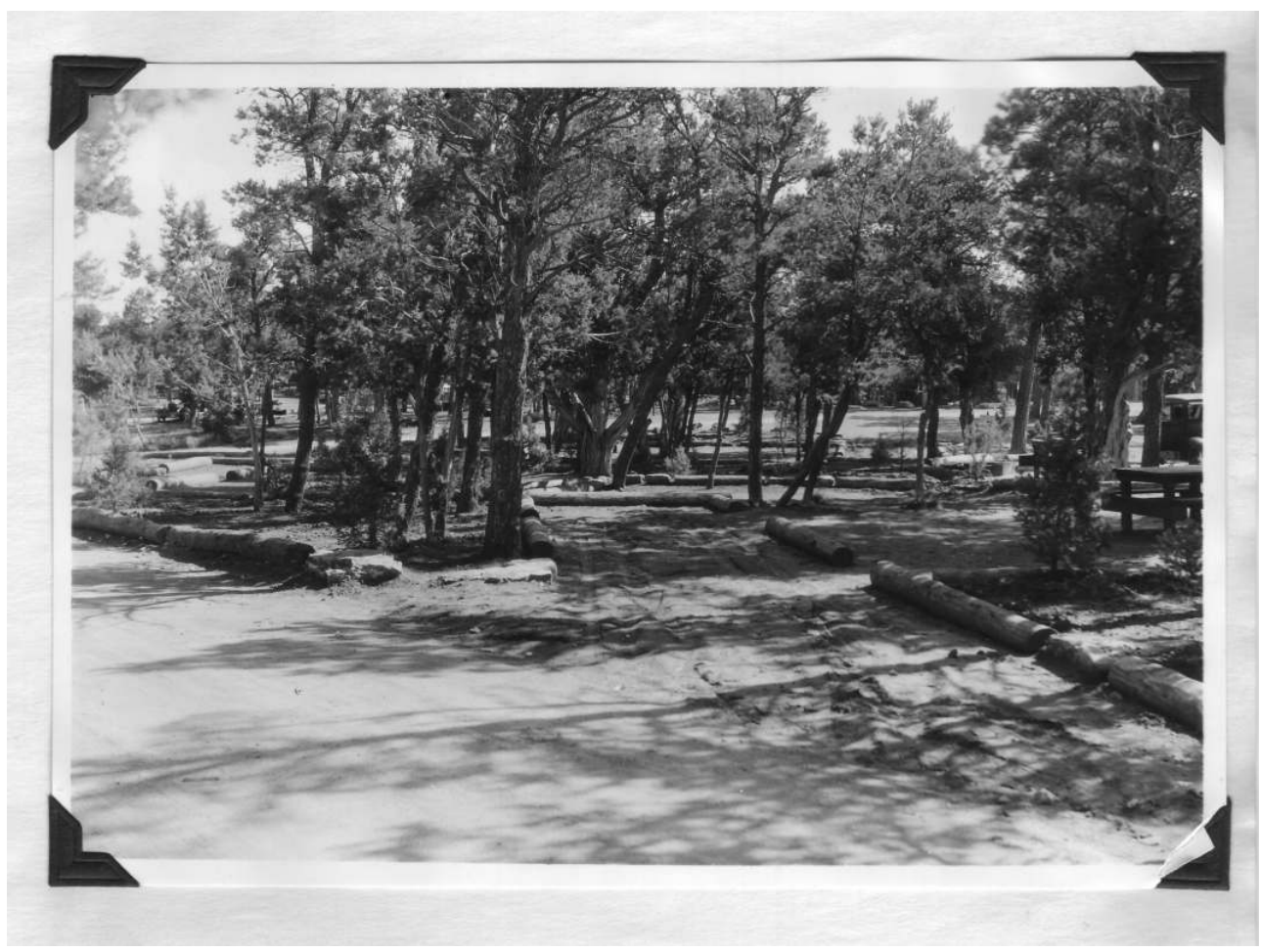

Figure 11. Meinecke-style campsites at Hearst San Simeon State Park, California in December 2014.

By author. 


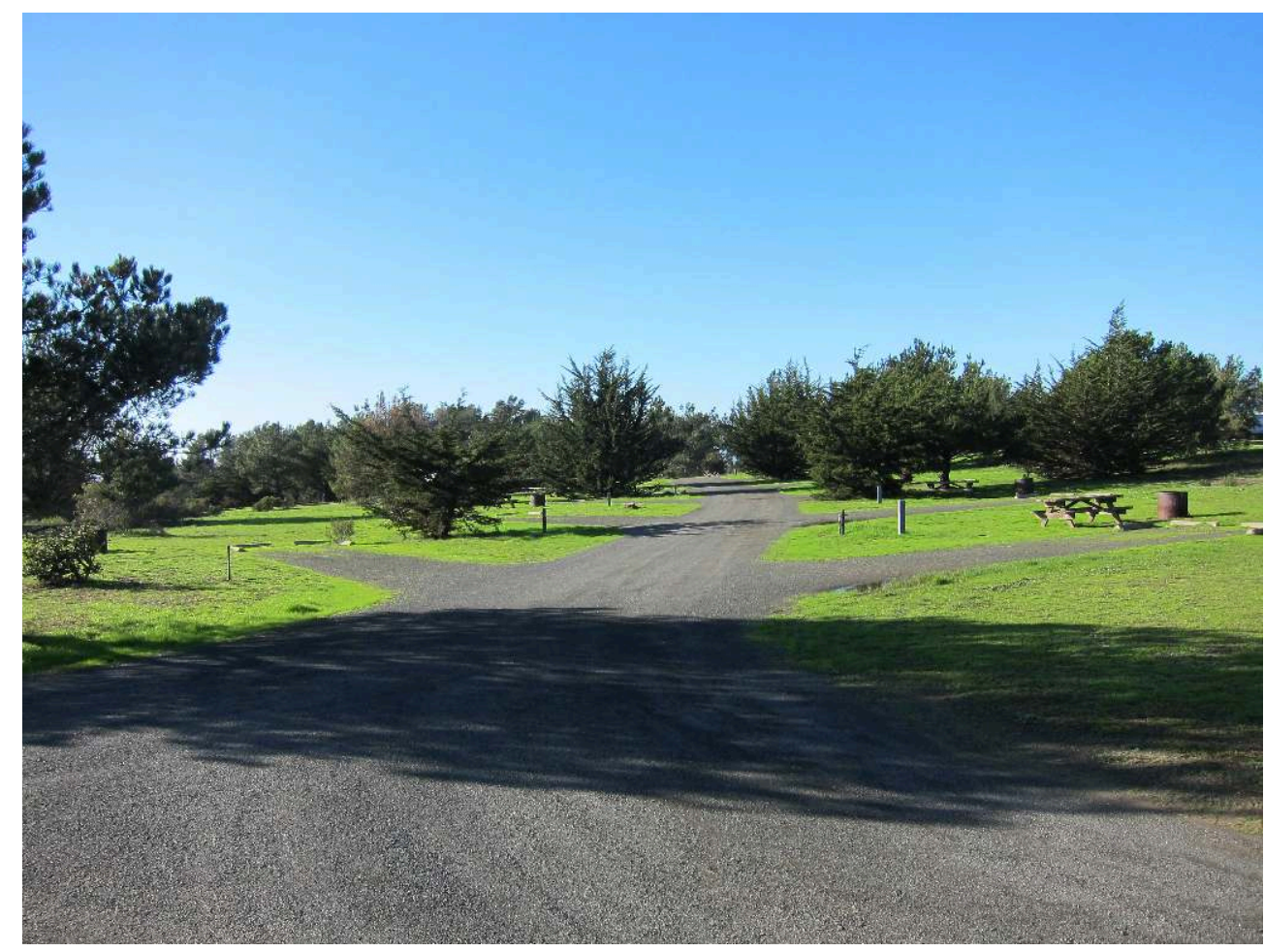

\section{A Modern Auto Campground}

Emilio P. Meinecke set out to protect the natural vegetation in America's campgrounds from unwitting damage inflicted by enthusiastic visitors. By introducing a variety of urban features, his campground proposals transformed an unregulated, chaotic, degrading and space-consuming situation into one where both managers and autocampers knew where the latter were supposed to set up their camps and what they should expect to find at each site. In addition, Meinecke's plan made more efficient use of a campground's space, potentially increasing the number of campsites during an era of rampant autocamping growth. Finally, Meinecke's plan enhanced management's ability to declare a campground full even as it controlled the autocampers and, most especially, tamed their automobiles. In a word, he modernized the campground by reimagining a natural space as a McDonaldized one.

Nevertheless, Meinecke also was sensitive to the motivations and expectations of autocampers. He emphasized the need to harmonize his modernist design with the natural landscape. No evidence suggests that he consciously considered autocampers to be anti-modern pilgrims, but he did understand that their desire to dwell in the wild was authentic, culturally shaped, and had to be incorporated into final landscape plans. Accordingly, Meinecke effectively balanced modern techniques with anti-modern sentiments.

Ironically, for all of Meinecke's plans to protect natural vegetation and his exhortations to employ indirect and naturalistic control measures, many autocampers became disillusioned with America's campgrounds over the next 40 years. His modernizing method was an environmental success in many ways, but it simultaneously reduced autocamping's "roughness," which is a critical aspect of any pilgrimage. The presence of fireplaces, tables, garage spurs, roads and soon more conveniences made 
autocamping more comfortable and less demanding than before. As a consequence, a growing number of campers in the post-WWII period began their exodus toward simpler, more basic and natural conditions. These campground emigrants would ultimately produce legions of backpackers during the 1960s and beyond. Despite his sentimental, anti-modern sensibilities, Meinecke's largely modernist approach would only be able to satisfy those who sought "the illusion of wildness," not wildness itself.

\section{BIBLIOGRAPHY}

Albright, Horace M., “A Forestry Policy for the National Parks” in Lary M. Dilsaver (ed.), America's National Park System: The Critical Documents, $2^{\text {nd }}$ Edition, Lanham, Rowman \& Littlefield, 2016, p. 75-88

Baker, Frederick S., “We Present: Emilio Pepe Michael Meinecke," Journal of Forestry vol. 46, 1948, p. 302

Berman, Marshall, All that is Solid Melts into Air: The Experience of Modernity, New York, Simon \& Schuster, 1982

Cadbury, Warder H., "Introduction" in William H.H. Murray, Adventures in the Wilderness; or, CampLife in the Adirondacks, William K. Verner (ed.), Syracuse, Syracuse University Press,1989

Carr, Ethan, Wilderness by Design: Landscape Architecture and the National Park Service, Lincoln, University of Nebraska Press, 1998

Dilsaver, Lary M., "Stemming the Flow: The Evolution of Controls on Visitor Numbers and Impacts in National Parks" in Lary M. Dilsaver and Craig E. Colten (eds.), The American Environment: Interpretations of Past Geographies, Lanham, Rowman \& Littlefield, 1992, p. 235-255

Giddens, Anthony, Conversations with Anthony Giddens: Making Sense of Modernity, Stanford, Stanford University Press, 1998

Good, Albert H. (ed.), Park Structures and Facilities, Washington, DC, US Government Printing Office, 1935

Good, Albert H., Park and Recreation Structures, Part III-Overnight and Organized Camp Facilities, Washington, DC, US Government Printing Office, 1938

Jackson, Kenneth T., Crabgrass Frontier: the Suburbanization of the United States, New York, Oxford University Press, 1985

McClelland, Linda Flint, Building the National Parks: Historic Landscape Design and Construction, Baltimore, The Johns Hopkins University Press, 1998

Meinecke, E.P., Memorandum on the Effects of Tourist Traffic on Plant Life, Particularly Big Trees, Sequoia National Park, California, May 13-16, 1926, Unpublished research report, 1926, in Archives, US Forest Service, Vallejo, CA

Meinecke, E.P., A Report Upon The Effect of Excessive Tourist Travel On the California Redwood Parks, Research report, Sacramento, California State Printing Office, 1928 
Meinecke, E.P., A Camp Ground Policy, Research report, 1932a in Emilio P. Meinecke papers, Box 8, California Academy of Sciences Library, San Francisco

Meinecke, E.P., A Camp Ground Policy, Research report, mimeographed typescript, April 2, 1932b in Camping, L3415, Office of Library, Archives and Graphics Research, National Park Service, Harpers Ferry Center, Harpers Ferry, WV

Meinecke, E.P. to Metcalf, Haven, April 8, 1932c in Records of the Bureau of Plant Industry, Soils and Agricultural Engineering, RG 54, Entry 80, Box 81, US National Archives, College Park, Maryland.

Meinecke, E.P. to Metcalf, Haven, July 8, 1932d in Records of the Bureau of Plant Industry, Soils and Agricultural Engineering, RG 54, Entry 80, Box 81, US National Archives, College Park, Maryland

Murray, William H.H., Adventures in the Wilderness; or, Camp-Life in the Adirondacks, William K. Verner (ed.), Syracuse, Syracuse University Press, 1989

Neville, Gwen Kennedy, Kinship and Pilgrimage: Rituals of Reunion in American Protestant Culture, New York, Oxford University Press, 1987

Ritzer, George, The McDonaldization of Society 5, Los Angeles, Pine Forge Press, 2008

San Francisco Examiner, “Dr. E.P. Meinecke, 88, Famed Botanist, Dies,” February 10, 1957

Schuyler, David, The New Urban Landscape; The Redefinition of City Form in Nineteenth-Century America, Baltimore, The Johns Hopkins University Press, 1986

Sears, John F., Sacred Places: American Tourist Attractions in the Nineteenth Century, New York, Oxford University Press, 1989

Shaffer, Marguerite S., See America First: Tourism and National Identity, 1880-1940, Washington, Smithsonian Institution Press, 2001

Statistical History of the United States from Colonial Times to the Present, Stamford, Fairfield Publishers, Inc., 1965

Stilgoe, John R., Borderland: Origins of the American Suburb, 1820-1939, New Haven, Yale University Press, 1988

Turner, Victor and Turner, Edith L.B., Image and Pilgrimage in Christian Culture, New York, Columbia University Press, 1978

Tweed, William C. and Dilsaver, Lary M., Challenge of the Big Trees, Revised Edition, Staunton, George F. Thompson Publishing, 2016

Wagener, W.W., Hartley, Carl, and Boyce, J.S., “Emilio Pepe Michael Meinecke,” Phytopathology , vol. 47, 1957, p. 633

White, John R. to Director, National Park Service, July 12, 1933 in Records of the National Park Service, RG 79, Appendix 2, Sequoia National Park, Box 1603, US National Archives, College Park, Maryland

Young, Terence, Building San Francisco's Parks, 1850-1930, Baltimore, The Johns Hopkins University Press, 2004

Young, Terence, “'Green and Shady Camps': E.P. Meinecke and the Restoration of America's Public Campgrounds," The George Wright Forum, vol. 31, no.1, 2014, p. 69-76

Young, Terence, Heading Out: A History of American Camping, Ithaca, Cornell University Press, 2017 


\section{NOTES}

1. Little has been published about E.P. Meinecke's automobile campground planning. See McClelland, L, 1998; Young, T, 2014; and Young, T, 2017.

2. See also Berman, M, 1982

3. Related phenomena include: residential suburbs, see Jackson, K, 1985 and Stilgoe, J, 1988; urban parks, see Schuyler, D, 1986 and, Young, T, 2004; and nationalistic tourism, see Sears, J, 1989 and Shaffer, M, 2001

4. Neville, G, 1987, identifies a variety of secular pilgrimage patterns in American life.

5. Meinecke's term - "indirect" - fits with contemporary National Park Service policies aimed at "harmonizing" artificial landscape features with surrounding natural ones, see Dilsaver, L, 1992; Carr, E.: and, McClelland, L, 1998. See also Tweed, W. and Dilsaver, L., 2016, p. 139, 142, which discusses the implementation of Meinecke's recommendations.

6. Meinecke continued to consult to the US Forest Service.

7. A printed version, Meinecke, E., 1932a, shortly followed the mimeograph. All page references are to this version of the report.

8. Approximately 0.1 hectare

\section{ABSTRACTS}

Recreational camping began in the United States in the 1860s after the conclusion of the American Civil War. It was an antimodern response to the rapid industrialization and urbanization that had begun to sweep through America. Americans embraced many of modernity's positive aspects, but they were uncomfortable with and worn down by the urban noise, pollution and many other negative characteristics that also came along. Camping emerged as a form of leisure-time pilgrimage to sacred nature in order to regenerate America's tired urban dwellers. Ironically, camping is not beyond the reach of modernity despite its antimodern roots. Camping's technology, practices, spaces and management have been shaped by the same modernizing forces that led to America's urban-industrial life. As the modern automobile became a central part of the camping experience during the 1920s, the number of campers increased dramatically causing the nature in and around public automobile campgrounds to deteriorate rapidly. The most widely embraced solution to this problem was created by E.P. Meinecke. A plant pathologist in the U.S. Department of Agriculture, he developed a modern version of the automobile campground that retained many of the antimodern elements sought by campers. Meinecke's design became the standard for U.S. national parks and forests.

Le camping, en tant que loisir, émerge aux États-Unis vers les années 1860, après la conclusion de la guerre de Sécession. Il constituait une réponse antimoderne aux rapides industrialisation et urbanisation qui se propageaient dans le pays. Les Nord-Américains ont embrassé de nombreux aspects positifs de la modernité, mais ils n'en ressentaient pas moins un inconfort et un sentiment d'alerte par rapport aux bruits du monde urbain, à la pollution et à bien d'autres autres effets collatéraux. Le camping s'est imposé comme un temps récréatif de pérégrination, consacrant un lien avec la nature, pour régénérer les Américains usés par la vie urbaine. Ironiquement, le camping n'est pas hors d'atteinte de la modernité, en dépit de ses fondements antimodernes. Les technologies du camping, les pratiques, les espaces et l'encadrement de 
l'activité ont été modelés par les mêmes forces modernisatrices qui ont configuré la vie américaine, à la fois urbaine et industrielle. Tandis que l'automobile est devenue un élément essentiel des activités de camping dans la décennie 1920, le nombre de campeurs a tant augmenté qu'il a eu de graves conséquences écologiques dans et autour des aires de stationnement. La solution la plus largement adoptée pour affronter ce problème a été créée par E.P. Meinecke. Ce phytopathologiste dans le département de l'Agriculture des États-Unis a développé une version moderne des aires de camping automobile en partant de nombreux éléments antimodernes prisés par les campeurs. Le modèle conçu par Meinecke est devenu un standard pour les parcs nationaux et forestiers américains.

El camping recreativo nació en los Estados Unidos en los años 1860, después de la guerra de Secesión. Surgió como una respuesta anti-moderna a los procesos de industrialización y urbanización que había comenzado a vivir el país. Aun cuando los estadounidenses aceptaban y aprovechaban los aspectos positivos de la modernidad, sus características negativas (el ruido y la contaminación, entre otras) les resultaban incómodas y agotadoras. El camping nació entonces como un pasatiempo semejante a una peregrinación hacia una naturaleza sagrada y regenerativa que contrastaba con las ruidosas urbes. Paradójicamente, esta actividad de raíces tan antimodernas no escapó totalmente a la modernidad: la tecnología, las prácticas y el tipo de gestión de los espacios que implica fueron moldeadas por las mismas fuerzas que guiaron la vida urbana e industrial de los Estados Unidos. En los años 1920 en particular, cuando el automóvil adquirió un rol fundamental para esta actividad, el número de adeptos aumentó drásticamente, causando el deterioro de la naturaleza colindante con las áreas de campamento automóvil. Fue entonces cuando E. P. Meinecke, un fitopatólogo del Departamento de Agricultura de los Estados Unidos, desarrolló una visión moderna de las áreas de campamento automóvil -incluyendo al mismo tiempo muchos de los elementos anti-modernos que buscaban los acampantes-, para hacer frente a este problema. Su modelo, el más ampliamente acogido en la época, se convirtió con el tiempo en el estándar adoptado por todos los parques y bosques nacionales estadounidenses.

\section{INDEX}

Mots-clés: camping, Meinecke, modernity, automobile, national parks

Palabras claves: campamento, Meinecke, modernidad, automóvil, parques nacionales

Keywords: camping, Meinecke, modernité, automobile, parcs nationaux

\section{AUTHOR}

\section{TERENCE YOUNG}

Terence Young is Professor of Geography at California State Polytechnic University. He is the author of Building San Francisco's Parks, 1850-1930 and coeditor of The Theme Park Landscapes: Antecedents and Variations. His areas of teaching and research expertise include historical geography, environmental geography, biogeography, and tourism \& recreation, particularly of the United States. He has published on nature perception and meaning, recreational environments, tourist landscapes, theme parks, and nature parks and reserves. 